\title{
Comentário a "AMOR E CONHECIMENTO: FREUd E ESPINOSA": EM BUSCA DA VIDA FELIZ
}

Homero Santiago ${ }^{1}$

Referência do artigo comentado: PAULA, M. F. de. Amor e conhecimento: Freud e Espinosa. Trans/form/açáo: revista de filosofia da Unesp, v. 44, n. 4, p. 291-320, 2021.

É um risco comentar o belo ensaio de Marcos Ferreira de Paula, pois as palavras perigam comprometer uma feliz combinação de clareza e generosidade conceitual na escrita, alternância entre a vista de detalhe e a de conjunto, na análise. Por exemplo, de que serviria implicar com as linhas aceleradas em que o Autor expóe o núcleo da questâo afetiva no espinosismo, em rodapés quase estenográficos? Seria desconhecer que tais explicaçóes cumprem prioritariamente a função de habilitar o leitor a seguir o Autor até a conclusão, que gira ao redor de tema complexo e (como sabemos, por outras publicaçóes suas) que lhe é caríssimo: a vida feliz. Restrinjo-me aqui, pois, a duas digressóes mais ou menos livres e a uma pergunta pontual.

${ }^{1}$ Professor do Departamento de Filosofia da Universidade de São Paulo (USP), São Paulo, SP - Brasil.
(D) https://orcid.org/0000-0002-0610-9993. E-mail: homero@usp.br. https://doi.org/10.1590/0101-3173.2021.v44n4.25.p321

(i) 
Mediante um cotejo preciso, Paula (2021) busca apreender algo da essência de dois pensadores, os quais, embora compartilhem uma mesma "atmosfera" (o termo é de Freud), assumem posturas diferentes, em certo sentido quase opostas, em face do saber, do amor e de sua relação com a vida. Talvez atiçado por uma menção incidental ao nome de Epicuro, não resisti a ler essa estratégia na esteira daquela da tese de doutorado de Marx: demonstrar que dois autores que a tradição ama aproximar muito se distanciam, quando descemos às minúcias téticas e às posturas que delas decorrem. Freud não estaria para Demócrito como Espinosa para Epicuro?

Demócrito é o homem que dedica a vida à ciência, e o mister se exprime numa atitude severa e distanciada relativamente ao mundo: vendo embora o sol pequeno, sabe que na verdade o astro é enorme. Em contraste, para Epicuro, o sol mede apenas dois pés, ou seja, é tal como aparece; a sua ciência tira do próprio mundo a verdade, pois está seguro de que este é o único mundo no qual se pode almejar uma vida feliz. Como sintetiza Marx (2018, p. 42), a diversidade nos posicionamentos acerca do saber se efetiva "[...] na disparidade da energia cientifica [wissenschaftlichen Energie] e da práxis desses homens". Em cada um, a energia teórica assume um destino próprio e redunda numa "energia prática" (praktisch Energie) (MARX, 2018, p. 46) diversa, configurando enfim dois instituta vite (fórmula espinosana a que voltaremos): num caso, a vida serve à verdade e ao saber; noutro, o saber e a verdade servem à vida. $\mathrm{O}$ primeiro é ansioso, furaria os próprios olhos para não ser cegado pelas aparências sensíveis; o segundo está satisfeito e feliz no canto de mundo que para si criou. "Ao passo que Demócrito é impelido a todas as regióes do mundo, Epicuro deixa seu jardim, quando muito, duas ou três vezes para ir a Atenas e viaja à Jônia não para fazer pesquisas mas para visitar amigos." (MARX, 2018, p. 46).

É impressionante como, no que se refere ao tema do amor e suas relaçóes com o saber, Freud revela traços do filósofo de Abdera. O austríaco não cogitou furar os próprios olhos, mas teria cultuado a "abstinência" sexual (parece ter aberto mão desses prazeres, a partir de certa altura da vida), à guisa de condição para a pesquisa da verdade. Espinosa, ao contrário, exibe um epicurismo certeiro, e vai além: não é que simplesmente o saber potencialize o afeto ou vice-versa, como se fossem duas coisas; o conhecimento é ele próprio 
um afeto vigoroso; uma ciência forte e correta produz alegria, assim como uma ciência falsa e débil só conduz à tristeza. Nesse sentido, a ciência intuitiva, mais que somente um gênero de conhecimento, seria também o nome de uma "energia" duradoura e voltada à beatitude humana - sem sublimação. A chave de tudo está na direção que se imprime ao saber e, por isso, declara Espinosa (2015b, p. 125) não the interessar explicar tudo, "[...] mas apenas o que nos pode levar, como que pela mão, ao conhecimento da mente humana e de sua suma felicidade."

\section{II}

Apresento brevemente uma pergunta. No Tratado da emenda do intelecto, Espinosa elenca três "bens", os quais, segundo os valores da "vida comum", seriam capazes de nos trazer a alegria: libido, honra, riquezas. $\mathrm{Na}$ verdade, nenhum desses bens é verdadeiramente um bem; pelo contrário, todos criam obstáculos à vida feliz. Analisando o entrecho, o Autor faz a seguinte observação: em Espinosa, "[...] o amor sexual é geralmente o mais forte, e nisso reconhecemos o gesto freudiano de colocar a paixáo sexual no centro da vida afetiva." Devo dizer não encontrei elementos que justifiquem a assertiva, nem no ensaio em questão, nem em outro do Autor, com tema semelhante e já antigo, que fui reler (PAULA, 2007). O que justifica, no âmbito do espinosismo, atribuir tamanha proeminência ao amor sexual (ou libido, tanto faz), em face de outros móbiles da vida comum?

\section{III}

O percurso do Autor se efetua mormente através da Ética e culmina no tópico do amor intelectual de Deus. É, porém, irresistível, quando perto do fim vem à baila o Tratado da emenda, querer reavaliar uma afirmação notória de Espinosa (2015a, \$9): “[...] toda a felicidade ou infelicidade está situada apenas no seguinte, a saber, na qualidade do objeto ao qual aderimos por amor." Tais palavras da inacabada obra juvenil, libertas da suspeiçáo de circunstancialidade, passam a emblemar um mote da inteira vida pensante espinosana. Em suma, remontando das conclusóes do Autor ao Tratado, coisas interessantes surgem, e tomo a liberdade de mencionar duas. 
Tendo em mente os primeiros parágrafos dessa obra, pergunto se não precisamos nuançar a discrepância - que o Autor afirma inconciliável - entre um Espinosa metafísico que deduz de Deus a problemática dos afetos e um Freud pouco dado a teses universais e que assenta a ciência na clínica e em casos individuais. Ora, no Tratado da emenda, embora efetivamente não encontremos uma "clínica", lemos uma narrativa em primeira pessoa de um "caso" individual (o do próprio filósofo) que se poderia posicionar em paralelo àquela autoanálise praticada por Freud, como gesto fundador da psicanálise.

O novum institutum vite que Espinosa alcança, mesmo sem configurar uma "cura", termina por instalar, nas bases da ciência, uma história de vida cujo pivô é a construção de um novo objeto de amor, do qual depende a nossa felicidade, que dá orientação à própria metafísica. Portanto, o ponto de vista mais alto não contradiz o mais baixo, antes por ele se orienta. Aliás, a Ética inteira talvez possa ser lida assim, como uma história de amor: a construção de um objeto (Deus) e de certa relação com ele (amor) que tenha um final feliz (beatitude). No fundo, a filosofia não seria só isso mesmo, um tipo de amor que enseja um determinado modo de vida?

Dessa perspectiva, ainda, convém reconhecer outra contribuição importante do ensaio em questáo. Para rumar ao sumo conhecimento, Espinosa (2015a, \$16) afirma ser necessário buscarmos uma via compreensiva que permita inteligir "[...] as coisas com felicidade, sem erro e da melhor maneira." Os leitores sempre ficaram intrigados pela referência a esse ato cognitivo realizado com felicidade, feliciter; tanto que os tradutores raramente ousam verter o termo literalmente (justiça seja feita, algo que faz a tradução aqui utilizada) preferindo subterfúgios ("com facilidade", "com sucesso").

Após ler o estudo de Marcos Ferreira de Paula, ficamos convencidos da justeza do advérbio, em sua precisa referência: a ciência espinosana é uma ciência que tem a felicidade não só por fim, mas como seu húmus e seu tônus; desde o início, é feliz, avança exercitando uma compreensão feliz e não tem outro objetivo senão a própria felicidade.

\section{REFERÊNCIAS}

ESPINOSA, B. Tratado da emenda do intelecto. Campinas: Editora da UNICAMP, 2015a.

ESPINOSA, B. Ética. São Paulo: EDUSP, 2015b. 
MARX, K. Diferença entre a filosofia da natureza de Demócrito e a de Epicuro. São Paulo: Boitempo, 2018.

PAULA, M. F. de. Espinosa, o sexo e outras alegrias. In: TATIÁN, D. (org.). Spinoza. Tercer colóquio. Córdoba: Brujas, 2007.

PAULA, M. F. de. Amor e conhecimento: Freud e Espinosa. Trans/form/açáo: revista de filosofia da Unesp, v. 44, n. 4, p. 291-320, 2021.

Recebido: 24/10/2020

Aceito: 27/10/2020 
SANTIAGO, $\mathrm{H}$. 